\title{
Genetic variation as a predictor of smoking cessation success. A promising preventive and intervention tool for chronic respiratory diseases?
}

\author{
M. Quaak*\#, C.P. van Schayck*, A.M. Knaapen" and F.J. van Schooten ${ }^{\#}$
}

ABSTRACT: Tobacco smoking continues to be the largest preventable cause of premature morbidity and mortality throughout the world, including chronic respiratory diseases such as asthma and chronic obstructive pulmonary disease. Although most smokers are highly motivated to quit and many smoking cessation therapies are available, cessation rates remain very low.

Recent research strongly suggests that variation in genetic background is an important determinant of smoking behaviour and addiction. Since these genetic variants might also influence the response to smoking cessation pharmacotherapies, it is likely that assessment of genetic background could be a promising tool to guide selection of the most effective cessation treatment for an individual smoker. Recently, it has been shown that genetic variants in the dopaminergic system, opioid receptors, the bupropion-metabolising enzyme CYP2B 6 and the nicotine-metabolising enzyme CYP2A6 may play an important role in predicting smoking cessation responses to nicotine replacement therapy and bupropion treatment. Despite the progress that has been made, several challenges will still have to be overcome before genetically tailored smoking cessation therapy can be implemented in standard clinical practice.

\section{KEYWORDS: Addiction, pharmacogenetics, smoking cessation}

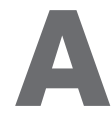

lthough the risk of cigarette smoking is well documented, tobacco smoking continues to be the largest preventable cause of disease and premature death throughout the world. It is estimated that there are currently still over 1.2 billion smokers worldwide, and this is expected to reach about $1.4-1.5$ billion in 2010 and $1.6-1.9$ billion by 2025 [1-4]. This is partly because of an increase in the adult population, and partly because of an increased consumption in low- and middle-income countries and among teenagers and females in high-income countries. Conversely, smoking prevalence among males in the high-income countries is declining $[1,4]$.

Inhalation of (cigarette) smoke has several deleterious effects on the airways, leading to and/or influencing chronic respiratory diseases such as asthma and chronic obstructive pulmonary disease (COPD). According to the latest World Health Organization estimates (in 2007), 300 million people have asthma and 210 million people have COPD. In contrast to other common smoking-related diseases, such as cardiovascular disease and cancer, chronic respiratory diseases are the only causes of death that are still increasing. By 2015, about 30\% of the smoking-related deaths will probably be caused by chronic respiratory diseases [5].

Cessation reverses most adverse effects of smoking $[6,7]$. Smoking cessation as early as possible is important, but cessation at any age results in significant life extension [6, 7]. Although the majority of smokers are highly motivated to quit, both smokers and healthcare practitioners are confronted with high relapse rates after initial
AFFILIATIONS

${ }^{*}$ Care and Public Health Research Institute (Caphri), Dept of General Practice, and

\#Nutrition and Toxicology Research Institute Maastricht (NUTRIM), Dept of Health Risk Analysis and Toxicology, Faculty of Health, Medicine and Life Sciences, Maastricht University, Maastricht, The Netherlands

\section{CORRESPONDENCE}

F.J. van Schooten, Nutrition and Toxicology Research Institute Maastricht (NUTRIM), Dept of Health Risk Analysis and Toxicology, Faculty of Health, Medicine and Life Sciences, Maastricht University, Universtiteitssingel 50, 6200 MD Maastricht, The Netherlands. Fax: 31433884146 ; E-mail: F.vanSchooten@ GRAT.unimaas.nl

Received:

April 152008

Accepted after revision:

November 182008

\section{SUPPORT STATEMENT}

This work has partly been supported by a grant from the Netherlands

Organisation for Health Research and Development (ZonMW, The Hague; Project No. 50-50101-96-404).

STATEMENT OF INTEREST None declared. 
TABLE 1 Efficacy of smoking cessation treatments

\begin{tabular}{|c|c|c|c|c|}
\hline Treatment type & Standard dose and duration & Quit rate $^{\#}$ (range) \% & $\begin{array}{l}\text { 6-12 months follow-up OR } \\
(95 \% \mathrm{Cl})\end{array}$ & Reference \\
\hline \multicolumn{5}{|c|}{ Behavioural counselling } \\
\hline Individual therapy & Weekly sessions of $10-60 \mathrm{~min}$ for $2-16$ weeks & $15.3(0-43)$ & $1.65(1.35-2.01)^{+}$ & [9] \\
\hline Group therapy & $1-3$ sessions $\cdot$ week $^{-1}$ of $45 \mathrm{~min}-2 \mathrm{~h}$ for $2-14$ weeks & $15.1(0-38)$ & $2.17(1.37-3.45)^{\S}$ & [10] \\
\hline Nortriptyline & $75-100 \mathrm{mg} \cdot \mathrm{day}^{-1}$ for $10-12$ weeks & $22.6(9-31)$ & $2.34(1.61-3.41)^{f}$ & [11] \\
\hline SSRIs & Dependent on type of SSRI used & $15.1(10-27)$ & $0.90(0.69-1.18)^{f}$ & [11] \\
\hline Venlafaxine & $225 \mathrm{mg} \cdot \mathrm{day}^{-1}$ for 8 weeks & 23.0 & $1.29(0.58-2.88)^{f}$ & {$[11]$} \\
\hline \multicolumn{5}{|c|}{ Nicotine replacement therapy } \\
\hline Gum & $\begin{array}{c}2-4 \mathrm{mg}\left(10-15 \text { doses }^{\text {day }}{ }^{-1} \text { recommended) for } 1-\right. \\
4 \text { months }\end{array}$ & $23.7(3-60)$ & $1.66(1.52-1.81)^{f}$ & [12] \\
\hline Inhaler/inhalator & $6-16$ cartridges $\cdot$ day $^{-1}$ for 12 weeks $(4 \mathrm{mg}$ ) & $20.2(11-28)$ & $2.14(1.44-3.18)^{f}$ & [12] \\
\hline Spray & $8-40$ doses $\cdot$ day $^{-1}\left(0.5 \mathrm{mg} \cdot\right.$ nostril $\left.^{-1}\right)$ for 8 weeks & $24.5(18-27)$ & $2.35(1.63-3.38)^{f}$ & [12] \\
\hline Tablets/lozenges & 9 lozenges $\cdot$ day $^{-1}$ for 6 weeks plus 6 -week tapering & $17.1(12-23)$ & $2.05(1.62-2.59)^{f}$ & [12] \\
\hline \multicolumn{5}{|c|}{ Nicotine receptor partial agonists } \\
\hline Varenicline & $0.5-1 \mathrm{mg} 1-2$ doses $\cdot$ day $^{-1}$ for $6-12$ weeks & $21.8(14-23)$ & $3.22(2.43-4.27)^{f}$ & [13] \\
\hline Cytisine & $\begin{array}{l}1.5 \mathrm{mg} \text { tabs } \\
\text { days 1-3: } 6 \text { tabs } \cdot \text { day }^{-1} \text {; } \\
\text { days 4-12: } 5 \text { tabs } \cdot \text { day }^{-1} \text {; } \\
\text { days 13-16: } 4 \text { tabs } \cdot \text { day }^{-1} \text {; } \\
\text { days 17-20: } 3 \text { tabs } \cdot \text { day }^{-1}\end{array}$ & 21.0 & $1.77(1.30-2.40)^{f . \# \#}$ & [13] \\
\hline \multicolumn{5}{|l|}{ Opioid antagonists } \\
\hline Naltrexone & $25-100 \mathrm{mg} \cdot \mathrm{day}^{-1}$ for $4-12$ weeks & $17.0(9-20)$ & $1.34(0.49-3.69)^{f}$ & [14] \\
\hline Acupuncture & $\begin{array}{l}\text { 4-20 sessions for 2-4 weeks; } \\
\text { indwelling needle for } 1-4 \text { weeks }\end{array}$ & $18.2(6-40)$ & $0.99(0.68-1.44)^{f}$ & [16] \\
\hline Laser therapy & 12 sessions for 4 weeks & 18.0 & $0.99(0.56-1.75)^{f}$ & [16] \\
\hline Electrostimulation & $5-8$ sessions of $20-60$ min for $1-3$ weeks & $35.2(27-40)$ & $1.23(0.72-2.09)^{f, \cdots}$ & [16] \\
\hline
\end{tabular}

OR: odds ratio; Cl: confidence ratio; SSRI: selective serotonin reuptake inhibitor; tabs: tablets. ${ }^{*}$ : weighted mean [9-16]; ": reference; ${ }^{+}$: versus "minimal contact" control; s. versus "no intervention"; ${ }^{\text {: }}$ versus placebo; ${ }^{\# \#: ~ 2-y r ~ f o l l o w-u p ; ~ " ~ ": ~ 6-m o n t h ~ f o l l o w-u p . ~}$

successful smoking cessation attempts. Despite progress made in the (pharmacological) treatment of nicotine dependence, the efficacy of available treatments is limited. As shown in table 1, only $15-30 \%$ of smokers continue to abstain from smoking [816]. Therefore, multiple quit attempts are often required.

Recent research strongly suggests that smokers vary in their underlying genetic susceptibility to become addicted to smoking [17-23]. Since pharmacogenetic therapies for smoking cessation are usually directed at the modulation of the pathways involved in smoking addiction, this genetic variation will probably also influence the efficacy of these smoking cessation therapies. Therefore, it seems that no medication will show efficacy for all smokers and the overall effectiveness of smoking cessation therapy might be increased if the therapy is targeted at those smokers most likely to respond. Research on the role of these inherited variations in the response to pharmacotherapy for nicotine addiction and smoking cessation may yield individualised treatments based on genotype. This is expected to result in a more efficient use of anti-smoking therapies, less frustration for smokers and more effort by healthcare providers in stimulating smoking cessation attempts. This will lead to increased cessation rates and, ultimately, in reduced deaths from chronic respiratory diseases caused by smoking. 
The aim of the present review is to discuss the relevance of genetic profiling of genes involved in mediating smoking behaviour and addiction, as a tool to guide selection of an individualised and more efficacious smoking cessation therapy. In addition, the usefulness of this approach as a tool to prevent smoking-related chronic respiratory diseases will be discussed. The most important chronic respiratory diseases caused by smoking will be reviewed, along with the candidate genes contributing to the variation in smoking behaviour. Finally, the current knowledge on smoking cessation therapy will be discussed in the light of genetic background.

\section{CHRONIC RESPIRATORY DISEASES ASSOCIATED WITH SMOKING}

Smoking has been shown to be the main risk factor in the development of COPD and is known to influence the progression and treatment of both COPD and asthma. In the next section, a brief overview of the relationship of smoking with COPD and asthma is provided.

\section{COPD}

COPD is a leading cause of morbidity and mortality worldwide and results in an economic and social burden that is both substantial and increasing [24-26]. Worldwide, COPD is the 12th most prevalent disease, the sixth most common cause of death and one of the few common causes of death increasing in incidence [24-26]. COPD is predicted to rise to the fourth most prevalent disease and the fourth most common cause of death by 2035 [5].

Smoking cessation is the most effective way to reduce the risk of developing COPD, since smoking accounts for 75-90\% of COPD cases in the developed world, and exposure to tobacco smoke leads to a higher risk of developing COPD and a higher rate of disease progression $[27,28]$. The rate of mortality from COPD in nonsmokers is less than $10 \%$ of that of lifetime smokers [29], and the number of deaths from COPD increases depending on the number of cigarettes smoked [29]. Even modest smoking (1-14 cigarettes-day $\left.{ }^{-1}\right)$ increases the rate of mortality from COPD by at least eight times compared with that of nonsmokers [29].

The impact of smoking cessation on respiratory symptoms, lung function, airway hyperresponsiveness and inflammation has been reviewed previously [30-33]. It has been shown that when a smoker with declined lung function stops smoking, they will not regain lung function already lost, but smoking cessation is the only intervention proven to rapidly revert the rate of decline in forced expiratory volume in one second (FEV1) to the usual age-related decline, for both males and females at all stages of COPD. Smoking cessation improves long-term prognosis and also reduces respiratory symptoms such as cough and sputum production. Furthermore, airway reactivity seemed to improve in a 5-yr follow-up study, but several cross-sectional studies showed no reduction in airway reactivity to direct stimuli in ex-smokers compared with current smokers. Additionally, although some indirect markers of airway inflammation suggest a reduction in inflammation after smoking cessation, ex-smokers seem to have persistent airway wall inflammation and often remain symptomatic and experience frequent exacerbations of their disease [30-33].
Furthermore, a pooled meta-analysis has shown that steroid treatment is probably less effective in COPD patients who continue to smoke [34].

\section{Asthma}

The prevalence of asthma increased worldwide during the last quarter of the 20th century, particularly among children and adolescents, making it the most common chronic illness of childhood, with a prevalence varying from 0 to $30 \%$ in different geographical areas. In many countries a gradual increase in asthma mortality has been seen over the last 50 yrs [35-37].

The health effects associated with exposure to passive smoking have been widely studied and reviewed [38-45]. Passive smoking, especially maternal smoking, in early childhood is reported to be associated with an increased risk for the development of asthma and more severe asthma symptoms, by impairing pulmonary function, enhancing airway reactivity and increasing pulmonary morbidity, leading to increased emergency department visits, hospitalisation rates and medication usage, and longer recovery periods after hospitalisation [38-45].

The health effects associated with active smoking have received less attention, since asthmatics are generally believed to be nonsmokers. However, the prevalence of smoking among adolescents with asthma has consistently been demonstrated to be equivalent to or even higher than rates among adolescents without asthma [42, 43, 46, 47], which means that about $15-35 \%$ of adult asthmatics are current smokers. Only a few reviews on the association of active smoking and asthma have been published [40-43, 47, 48]. Smoking asthmatics have been shown to have worse symptom control than nonsmoking asthmatics, about four times more asthma attacks, an accelerated decline in lung function (FEV1) and increased pulmonary problems, such as a higher chance of respiratory failure and arrest, increased airway inflammation, more exacerbations, an exaggerated bronchoconstrictor response, a higher mortality rate after admission with a near-fatal asthma attack, and a higher chance of hospitalisation for intubation. The severity of these complications is positively related to the number of cigarettes smoked [40-43, 47, 48].

In addition, several studies have found that the efficacy of inhaled or oral corticosteroid treatment is also impaired in smokers with chronic asthma [47, 48].

\section{CANDIDATE GENES FOR THE VARIATION IN SMOKING BEHAVIOUR}

Tobacco smoking is believed to be a complex, multifactorial behaviour with both genetic and environmental determinants. While early reports suggested that the influence of heredity on smoking was modest, more recent studies have found significant genetic influences on several aspects of smoking behaviour. It has been demonstrated that genetic factors account for approximately $40-75 \%$ of the variation in smoking initiation, $70-80 \%$ of the variation in smoking maintenance, about $50 \%$ of the variance in cessation success and $30-50 \%$ of the variance in risk of withdrawal symptoms [17-23, 49, 50].

Variations in several genes have been suggested to contribute to smoking behaviour, and research has been focused on two 
broad classes of candidate genes: 1) genes that may influence the response to nicotine (e.g. nicotine metabolism, nicotinic receptors) and 2) genes that may predispose to addictive behaviour due to their effects on key neurotransmitter pathways (e.g. dopamine and serotonin) [23, 51-54].

In the next section, the most important candidate genes for the variation in smoking behaviour will be briefly discussed.

\section{Genes influencing the response to nicotine}

Nicotine is the primary reward component in tobacco products. Therefore, genes involved in the metabolism of nicotine are biologically plausible candidates for genetic studies of smoking behaviour, because they determine the levels and persistence of nicotine in the body. It is hypothesised that individuals with a high nicotine metabolism may experience fewer adverse reactions to their first encounter with nicotine and, therefore, may have a greater chance of continuing smoking and becoming addicted. Conversely, slow nicotine metabolisers may be less prone to initiate smoking because they may experience more adverse effects and would require fewer cigarettes to maintain nicotine titres at an optimal level once smoking is initiated [55]. The major genes responsible for the metabolism of nicotine are the hepatic enzymes cytochrome P450 2A6 (CYP2A6) and cytochrome P450 2D6 (CYP2D6; fig. 1).

Of these, CYP2A6 is believed to be the most important predictor of the rate of nicotine metabolism, because it is responsible for roughly $90 \%$ of the metabolic inactivation of nicotine to cotinine [56,57]. A number of studies have shown that individuals carrying $C Y P 2 A 6$ variants that reduce the enzyme activity, determined in vivo via the measurement of the cotinine/nicotine or trans-3'-hydroxycotinine/cotinine ratios in blood or urine, are less tobacco dependent, smoke significantly fewer cigarettes per day and have an increased likelihood of quitting smoking [55, 58-62]. Other studies have failed to detect these associations $[63,64]$ and a meta-analysis reviewing several studies on CYP2A6 genotype and smoking also found no association with smoking status and number of cigarettes smoked [65].

In addition, several studies have investigated the effects of CYP2D6 polymorphisms. Polymorphisms in CYP2D6 do not seem to be major determinants of nicotine metabolism in smokers except in ultrametabolisers (gene duplication) [66].

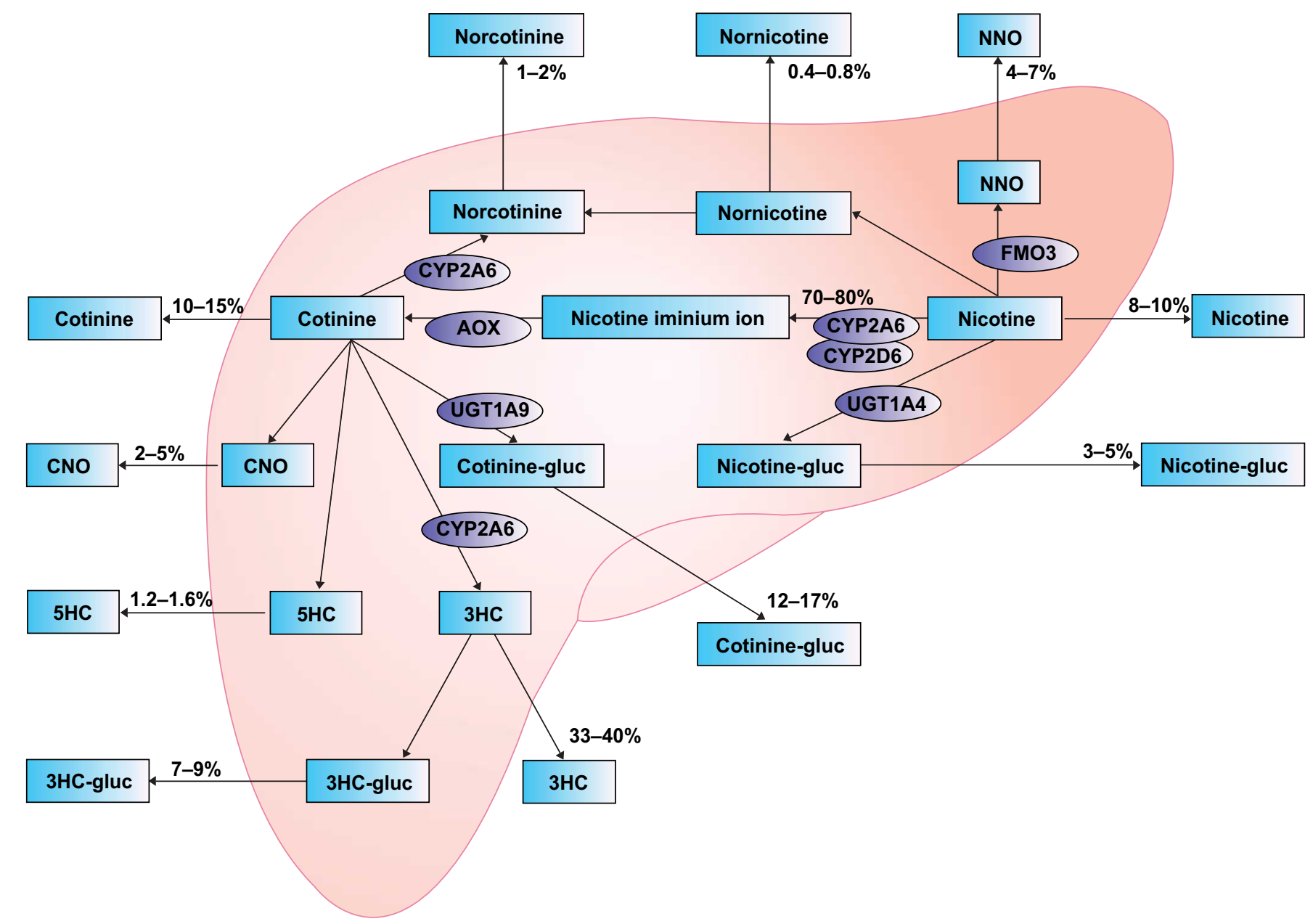

FIGURE 1. Nicotine metabolism in the human liver. NNO: nicotine-1'-N-oxidase; CYP2A6: cytochrome P450 2A6; FMO3: flavin-containing monooxygenase 3; AOX: aldehyde-oxidase; CYP2D6: cytochrome P450 2D6; CNO: cotinine-N-oxide; UGT: uridine diphosphate-glucuronosyltransferase; cotinine-gluc: cotinine-glucuronide; nicotinegluc: (S)-nicotine-glucuronide; 5HC: 5'-hydroxycotinine; 3HC: 3'-hydroxycotinine; 3HC-gluc: 3'-hydroxycotinine-glucuronide. 
This is probably because its catalytic activity towards nicotine is negligible in the presence of functional CYP2A6. Ultrametabolisers were found to be more likely to be heavy smokers [67]. No relationship has been found for individuals with a poor CYP2D6 metabolism $[67,68]$, although one study did find a trend towards more poor metabolisers among males in the nonsmoking group [67], and another study reported that a poor CYP2D6 metabolism may reinforce smoking behaviour in committed smokers [69].

The pharmacological effects of nicotine are mediated by the activation of nicotinic acetylcholine receptors (nAChRs). Highaffinity nicotinic receptors mainly contain the $\alpha_{4}$ (CHRNA4) and $\beta_{2}$ (CHRNB2) subunits, and $\alpha_{4} \beta_{2}{ }^{*}{ }^{*}$ indicates that another subunit may be included) is the most frequently encountered nicotinic receptor subtype. Several $\mathrm{nAChR}$ subunit genes have been examined for associations with smoking status (e.g. CHRNA4, CHRNA5, CHRNA7, CHRNB1, CHRNB2 and CHRNB3), but the functional relevance of the investigated variants in these genes is not yet known. Some evidence for an association with tobacco dependence and smoking status for variants in CHRNA5, CHRNA7, CHRNB1 and CHRNB3 [70-72] has been provided. Evidence on the association of variants in the CHRNB2 and CHRNA4 genes is inconclusive [73-78].

\section{Genes involved in the dopamine pathway}

The mesolimbic dopamine system has been proven to play an important role in nicotine's rewarding effects [79-82].
Therefore, investigators have examined the association between smoking behaviour and variations in several genes involved in the dopamine pathway, such as dopamine receptors, the dopamine transporter and enzymes involved in dopamine synthesis and metabolism (fig. 2).

Variants in several dopamine receptor genes (e.g. DRD1, $D R D 2, D R D 4$ and DRD5) have been detected and studied in relation to smoking behaviour. Overall, genotypes associated with reduced dopamine receptor expression or function seem to predict a higher chance of becoming a smoker, a younger age of onset, and fewer and less successful quit attempts [83-92]. This is probably because subjects with reduced numbers of dopamine receptors may compensate for this deficiency by using nicotine to increase brain dopamine levels. However, the evidence concerning such results is still inconclusive [52, 93-95].

The dopamine transporter moves the dopamine released in the synapse into a neuron, glial cell or astrocyte to terminate the dopamine signal. A reduction in dopamine transporter levels, resulting in less clearance and greater bio-availability of dopamine, has been shown to be related to a lower chance of becoming a smoker, a lower nicotine intake and longer periods of smoking cessation [96, 97], but also, among African American smokers, to increased craving [98]. Other studies failed to replicate these results $[99,100]$.

Several enzymes, such as tyrosine hydroxylase (TH), 3,4dihydroxyphenylacetic acid decarboxylase (DDC), dopamine

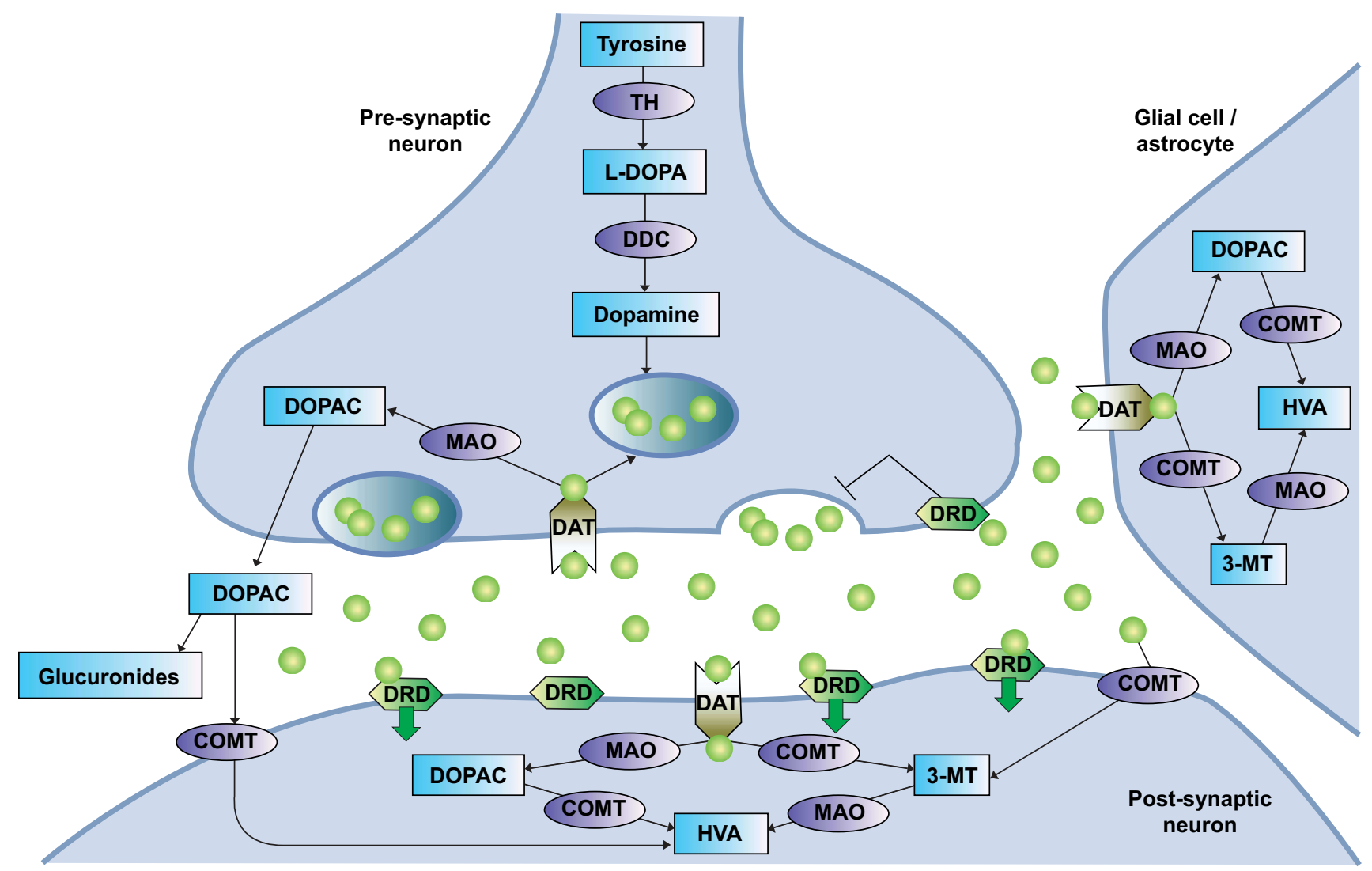

FIGURE 2. The dopamine pathway. TH: tyrosine hydroxylase; L-DOPA: L-3,4-di-hydroxy-phenylalanine; DDC: 3,4-dihydroxyphenylacetic acid (DOPAC) decarboxylase MAO: monoamine oxidase; DAT: dopamine transporter; DRD: dopamine receptor; COMT: catechol-O-methyltransferase; HVA: homovanillic acid; 3-MT: 3-methoxytyramine. Green circles: dopamine. 
$\beta$-hydroxylase (DBH), catechol-O-methyl-transferase (COMT) and monoamine oxidase (MAO)-A and $-\mathrm{B}$, are involved in the synthesis and metabolism of dopamine. Only limited data on the effects of variations in these enzymes on smoking behaviour are available. Associations between smoking and variations in genes for $M A O-A, M A O-B, D B H$ and $D D C$ have been found [101-107]. No associations for most variants in $T H$ have been reported; however, one variant seems to protect against smoking [101, 108-110]. Contradicting results have been found for an increased activity COMT variant: some studies have found a positive association between the variant and nicotine dependence and smoking cessation [111-114], while others did not find an association [101, 112].

\section{Genes involved in the serotonin pathway}

The serotonin pathway is also under investigation in genetic studies of smoking, for several reasons. First, nicotine has been shown to increase the secretion of serotonin in the brain [115, 116]. Secondly, increased serotonin levels have been associated with decreased food intake and weight gain, and have been shown to have an antidepressant effect [115]. Furthermore, lower serotonin re-uptake has been associated with several behavioural traits (e.g. neuroticism, novelty seeking and anxiety-related personality traits) that are related to an increased incidence of smoking, increased nicotine dependence and difficulty in quitting smoking $[117,118]$. Candidate polymorphisms include those involved in serotonin biosynthesis (e.g. tryptophan hydroxylase $(\mathrm{TPH})$ ) and serotonin reuptake (e.g. serotonin transporter (5-HTT)). Individuals homozygous for a variant of $\mathrm{TPH}$, with an unknown effect, have been shown to be more prone to initiate smoking and to start smoking at an earlier age, but no effect on progression to nicotine dependence and smoking status has been found [119121]. Other studies have found that lower 5-HTT levels are associated with increased neuroticism in nicotine dependence $[117,118]$. Another study was unable to detect an association [122]. Conversely, in a Japanese population, increased 5-HTT levels appeared to be associated with smoking [123].

\section{INFLUENCE OF GENETIC VARIATIONS ON SMOKING CESSATION TREATMENT}

Since the genetic background of mechanisms influencing smoking behaviour and addiction varies between smokers, it is a logical step to assess whether this genetic variation also determines the efficacy of smoking cessation treatment. Research on the role of such inherited genetic variation in the response to pharmacotherapy for smoking cessation opens avenues for individually tailored smoking cessation treatment based on genetic background. This might improve efficacy and minimise toxicity and side-effects of the treatments.

Most research on the role of genetic variation on smoking cessation pharmacotherapy has been directed to the two most

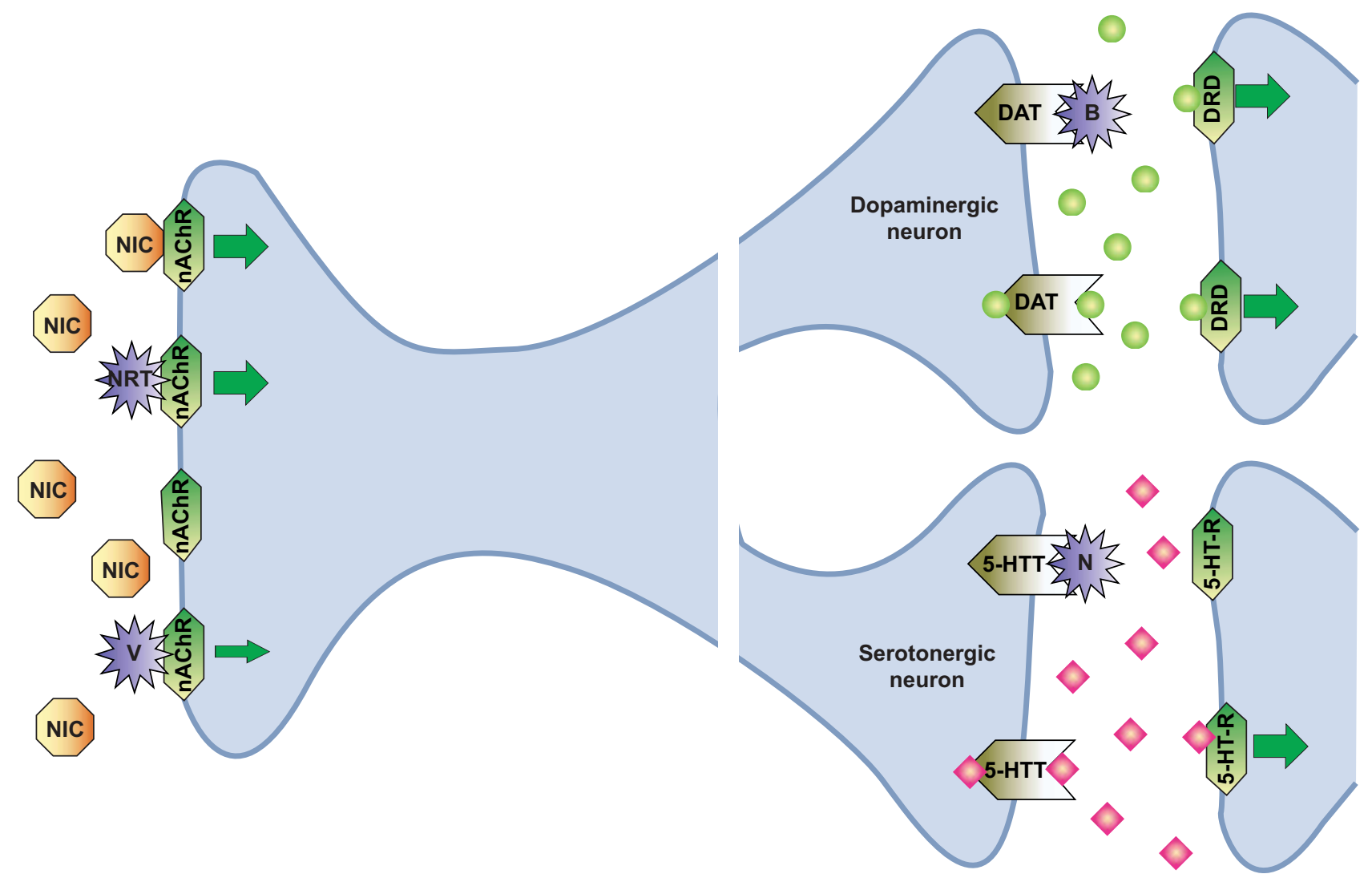

FIGURE 3. Mechanisms of smoking cessation treatments. Nicotine replacement therapy (NRT) partly replaces the nicotine (NIC) from smoking. Varenicline (V) blocks nicotinic acetylcholinic receptors (nAChRs), but still triggers dopamine release (green circles). Bupropion (B) inhibits re-uptake of dopamine, by occupying the dopamine transporter (DAT), thereby increasing the amount of dopamine to bind to post-synaptic dopamine receptors (DRDs). Nortriptyline (N) inhbits re-uptake of serotonin (red diamonds) by occupying the serotonin transporter (5-HTT), leading to increased amounts of serotonin to bind to post-synaptic serotonin receptors (5-HT-Rs). 
widely accepted and licensed forms of smoking cessation therapy: nicotine replacement therapy (NRT) [111, 124-140] and the antidepressant bupropion $\left(Z^{2 y b a n}{ }^{\circledR}\right)$ [129, 137, 141-149].

The relationship between genetic variation and efficacy of NRT can be illustrated by the following. First, it has been shown that smokers with genotypes associated with reduced dopamine levels (reduced dopamine receptor availability or function, high dopamine transporter levels and higher dopamine metabolism) achieve better quit rates with NRT compared with placebo [111, 124, 126, 127, 129, 134, 137, 139]. Secondly, smokers who carry genetic polymorphisms associated with reduced nicotinic receptor (and possibly also dopaminergic) activity may experience greater benefit from nicotine spray (NS) compared with transdermal nicotine patches (TN), because of the greater rewarding effects of NS [133]. Thirdly, smokers who have increased activity variants in the $\mu$-opioid receptor $(M O R)$ may have better success with the higher levels of nicotine delivered by TN compared with the lower levels of nicotine from NS $[125,136,138]$, possibly only in combination with variants in MOR-interacting proteins [138]. Fourthly, an increased nicotine metabolism (determined primarily by CYP2A6 genotype but probably not by CYP2B6 genotype) lowers quit rates with TN $[128,130,135]$. Fifthly, variants in 5HTT do not seem to influence the response to NRT [131, 132].

The efficacy of the antidepressant bupropion also seems to be related to a specific genetic background. First, genotypes associated with increased dopamine availability (increased or normal dopamine receptor availability or function, low dopamine transporter levels and low dopamine metabolism) predict a better response to bupropion [129, 137, 142-147, 149].
Secondly, bupropion also seems to be more effective in smokers with a decreased bupropion metabolism (e.g. CYP2B6 decreased activity variants) [141, 148], but less effective in the presence of a decreased CYP2A6 metabolism [148]. However, the influence of variants in the serotonin pathway on bupropion efficacy has not yet been investigated.

Despite all the progress that has been made in unravelling the pharmacogenetics of smoking cessation therapies, this research is still in its infancy and many challenges still have to be overcome before genetically tailored smoking cessation strategies can be effectively integrated into standard clinical practice.

First, so far, most studies have investigated only single genes. This approach will probably fail to fully determine the role of genetic variation in the individual susceptibility to smoking cessation therapies, since a large number of genes and polymorphisms in these genes are likely to contribute.

Secondly, until now, the pharmacogenetics have been investigated for only a couple of smoking cessation therapies. Newer compounds (e.g. varenicline), as well as current secondline medications for smoking cessation (e.g. nortriptyline), will also require investigation. Varenicline has been shown to bind with high affinity and selectivity at $\alpha_{4} \beta_{2}$ receptors, thereby stimulating dopamine release while simultaneously preventing nicotine from binding (fig. 3). Therefore, varenicline is expected to be more effective in smokers with genotypes associated with reduced dopamine availability, in a similar manner to NRT. Since nortriptyline has antidepressant properties, like bupropion, nortriptyline is expected to be more effective in smokers with genotypes associated with increased

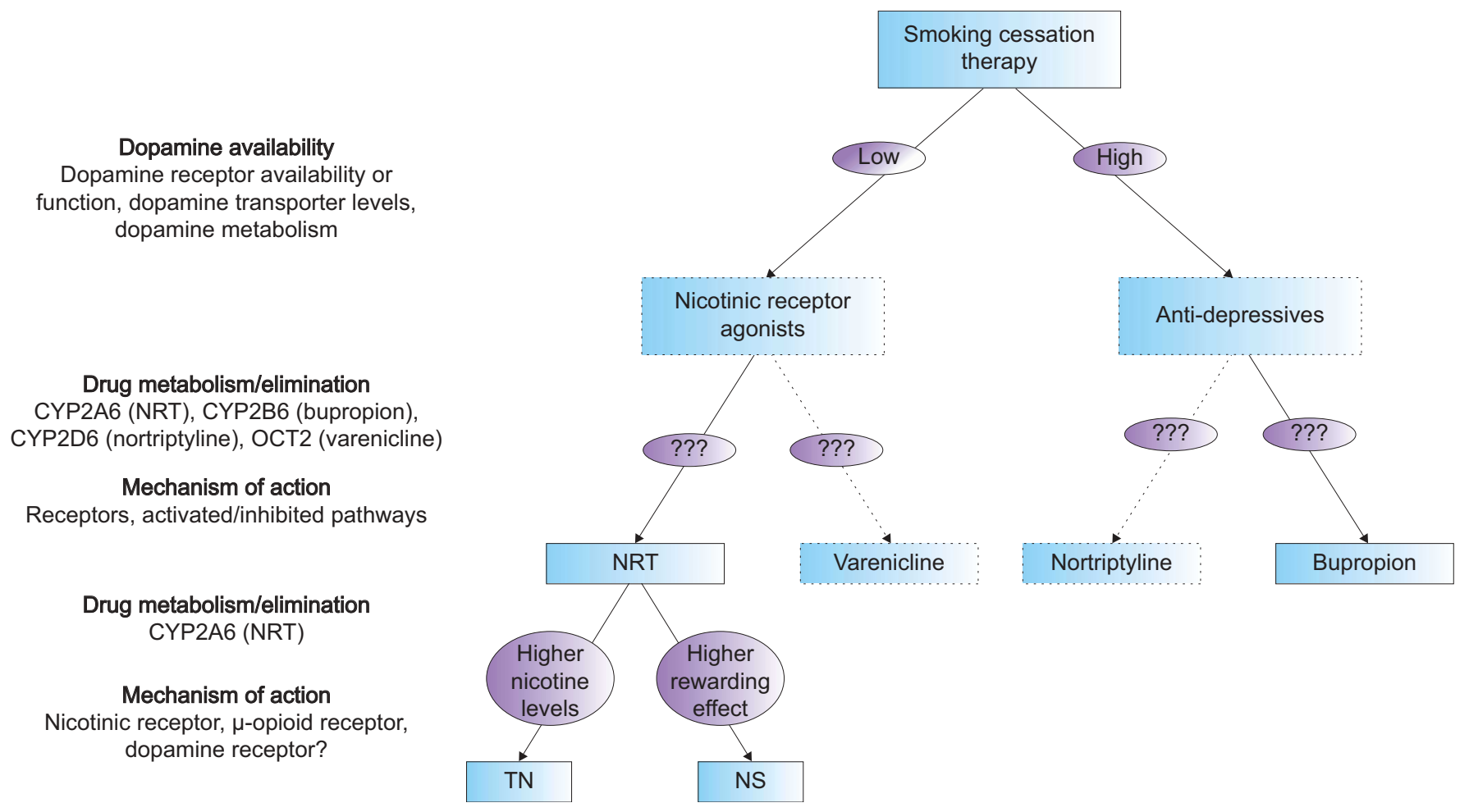

FIGURE 4. Hypothetical model for genetically tailored smoking cessation therapy. NRT: nicotine replacement therapy; CYP2A6: cytochrome P450 2A6; CYP2B6: cytochrome P450 2B6; CYP2D6: cytochrome P450 2D6; OCT2: organic cation transporter 2; TN: transdermal nicotine patch; NS: nicotine nasal spray. 
dopamine availability. However, differences in the metabolism or elimination of these drugs, as well as pathways involved in the mechanism of action, could make one drug more effective than the other or result in fewer side-effects in certain subgroups of smokers. In figure 4 it is hypothesised how smoking cessation therapy might be genetically tailored based on present knowledge.

Thirdly, genetic associations with tolerability and side-effects should also be examined. It is likely that some individuals are predisposed to have unusual reactions to drugs due to the presence of certain genetic defects. For example, it has been shown that variation in the DRD2 gene results in increased side-effects and thereby decreased adherence among females treated with bupropion [144]. Certain subgroups of individuals may also exist who respond well to certain medications that are normally not well tolerated. For instance, individuals with a high nicotine metabolism may benefit from high-dose nicotine patches without experiencing the generally occurring side-effects.

Fourthly, a marked racial/ethnic diversity exists in smoking behaviour (e.g. age of initiation, smoking rate and level of dependence) and in the frequency of functional polymorphisms. To date, the vast majority of studies have been conducted with Caucasians, simply to avoid population stratification. Thus, the effect of genetic variants in other racial/ethnic groups should be investigated as well.

Fifthly, some research suggests that pharmacotherapies might work through different processes and/or be subject to different genetic influences in males and females. Therefore, the effect of genetic variations should be assessed for males and females separately.

Furthermore, the findings should be validated across independent trials, and prospective studies should be set up to fully confirm the effect of the variants.

Finally, several practical, policy and ethical considerations have to be addressed. Additional research should be conducted to examine the benefits, risks and challenges of conveying genetic information about smoking predisposition to the patient, clinicians and the public. Economic analyses of the cost-effectiveness of using genotype information to tailor smoking treatment would also be necessary and appropriate legal and regulatory frameworks should be set up to ensure privacy and to protect against genetic discrimination.

\section{CONCLUSIONS}

Health promotion and health education regarding tobacco use has made the public aware of the dangers of smoking and has resulted in increased cessation rates, but many smokers still continue to smoke, leading to high morbidity and mortality rates, especially from chronic respiratory diseases such as COPD and asthma. Although many of these smokers are highly motivated to quit, only a small proportion of individuals respond to the various treatments that are currently available to aid long-term smoking cessation. Since smoking behaviour has been shown to be influenced by genetic variations, it is expected that genetic variants might also influence smoking cessation success.
Based on recent research, it seems that genetic variants in several pathways related to smoking behaviour influence success rates of smoking cessation therapies. The effects of smoking cessation therapy might thus also differ considerably in subgroups carrying certain genetic variants. Therefore, a profile of genetic variants in these smoking-related pathways could possibly be used to predict in advance which smoking cessation therapy is likely to be most effective for an individual smoker. This could lead to a more effective use of smoking cessation therapies, resulting in fewer side-effects and increased cessation rates, and ultimately in reduced morbidity and mortality from chronic respiratory diseases such as COPD and asthma.

However, before genetically tailored smoking cessation therapy can be implemented in clinical practice, future studies should investigate the effect of multiple susceptibility genes, as well as their mutual interactions on several smoking cessation therapies, in large-scale, comparable trials in different ethnic/ racial groups and different sexes. Additionally, prospective trials should be set up to fully confirm the effect of the variants.

\section{REFERENCES}

1 Curbing the epidemic: governments and the economics of tobacco control. The World Bank. Tob Control 1999; 8: 196-201.

2 Steptoe A, Wardle J, Cui W, et al. An international comparison of tobacco smoking, beliefs and risk awareness in university students from 23 countries. Addiction 2002; 97: 1561-1571.

3 The world health report 2003 - shaping the future. Geneva, World Health Organization, 2003.

4 Guindon GE, Boisclair D. Past, current and future trends in tobacco use. HNP discussion paper. Econcomics of tobacco control paper no. 6. Washington, The World Bank, 2003.

5 Mathers CD, Loncar D. Projections of global mortality and burden of disease from 2002 to 2030. PLoS Med 2006; 3: e442.

6 Taylor DH Jr, Hasselblad V, Henley SJ, Thun MJ, Sloan FA. Benefits of smoking cessation for longevity. Am J Public Health 2002; 92: 990-996.

7 Doll R, Peto R, Boreham J, Sutherland I. Mortality from cancer in relation to smoking: 50 years observations on British doctors. Br J Cancer 2005; 92: 426-429.

8 Lancaster T, Stead L, Silagy C, Sowden A. Effectiveness of interventions to help people stop smoking: findings from the Cochrane Library. BMJ 2000; 321: 355-358.

9 Lancaster T, Stead LF. Individual behavioural counselling for smoking cessation. Cochrane Database Syst Rev 2002; 3: CD001292.

10 Stead LF, Lancaster T. Group behaviour therapy programmes for smoking cessation. Cochrane Database Syst Rev 2005; 2: CD001007.

11 Hughes JR, Stead LF, Lancaster T. Antidepressants for smoking cessation. Cochrane Database Syst Rev 2007; 1: CD000031.

12 Silagy C, Lancaster T, Stead L, Mant D, Fowler G. Nicotine replacement therapy for smoking cessation. Cochrane Database Syst Rev 2004; 3: CD000146. 
13 Cahill K, Stead LF, Lancaster T. Nicotine receptor partial agonists for smoking cessation. Cochrane Database Syst Rev 2007; 1: CD006103.

14 David S, Lancaster T, Stead LF, Evins AE. Opioid antagonists for smoking cessation. Cochrane Database Syst Rev 2006; 4: CD003086.

15 Gourlay SG, Stead LF, Benowitz NL. Clonidine for smoking cessation. Cochrane Database Syst Rev 2004; 3: CD000058.

16 White AR, Rampes H, Campbell JL. Acupuncture and related interventions for smoking cessation. Cochrane Database Syst Rev 2006; 1: CD000009.

17 Kaprio J, Hammar N, Koskenvuo M, Floderus-Myrhed B, Langinvainio H, Sarna S. Cigarette smoking and alcohol use in Finland and Sweden: a cross-national twin study. Int J Epidemiol 1982; 11: 378-386.

18 Heath AC, Cates R, Martin NG, et al. Genetic contribution to risk of smoking initiation: comparisons across birth cohorts and across cultures. J Subst Abuse 1993; 5: 221-246.

19 Heath AC, Martin NG. Genetic models for the natural history of smoking: evidence for a genetic influence on smoking persistence. Addict Behav 1993; 18: 19-34.

20 True WR, Heath AC, Scherrer JF, et al. Genetic and environmental contributions to smoking. Addiction 1997; 92: 1277-1287.

21 Kendler KS, Neale MC, Sullivan P, Corey LA, Gardner CO, Prescott CA. A population-based twin study in women of smoking initiation and nicotine dependence. Psychol Med 1999; 29: 299-308.

22 Sullivan PF, Kendler KS. The genetic epidemiology of smoking. Nicotine Tob Res 1999; 1: Suppl. 2, S51-S57.

23 Batra V, Patkar AA, Berrettini WH, Weinstein SP, Leone FT. The genetic determinants of smoking. Chest 2003; 123: 1730-1739.

24 Murray CJ, Lopez AD. Mortality by cause for eight regions of the world: Global Burden of Disease Study. Lancet 1997; 349: 1269-1276.

25 Barnes PJ. Chronic obstructive pulmonary disease. N Engl J Med 2000; 343: 269-280.

26 Pauwels RA, Buist AS, Calverley PM, Jenkins CR, Hurd SS, GOLD Scientific Committee, Global strategy for the diagnosis, management, and prevention of chronic obstructive pulmonary disease. NHLBI/WHO Global Initiative for Chronic Obstructive Lung Disease (GOLD) Workshop summary. Am J Respir Crit Care Med 2001; 163: 1256-1276.

27 Siafakas NM, Vermeire P, Pride NB, et al. Optimal assessment and management of chronic obstructive pulmonary disease (COPD). The European Respiratory Society Task Force. Eur Respir J 1995; 8: 1398-1420.

28 The health consequences of smoking: a report of the Surgeon General. Atlanta, U.S. Department of Health and Human Services, 2004. Available from http://www.cdc. gov/tobacco/data_statistics/sgr/sgr_2004/index.htm.

29 Doll R, Peto R, Wheatley K, Gray R, Sutherland I. Mortality in relation to smoking: 40 years' observations on male British doctors. BMJ 1994; 309: 901-911.

30 Sethi JM, Rochester CL. Smoking and chronic obstructive pulmonary disease. Clin Chest Med 2000; 21: 67-86.

31 Willemse BWM, Postma DS, Timens W, Ten Hacken NHT. The impact of smoking cessation on respiratory symptoms, lung function, airway hyperresponsiveness and inflammation. Eur Respir J 2004; 23: 464-476.

32 Bartal M. COPD and tobacco smoke. Monaldi Arch Chest Dis 2005; 63: 213-225.

33 Hylkema MN, Sterk PJ, de Boer WI, Postma DS. Tobacco use in relation to COPD and asthma. Eur Respir J 2007; 29: 438-445.

34 Sin DD, Wu L, Anderson JA, et al. Inhaled corticosteroids and mortality in chronic obstructive pulmonary disease. Thorax 2005; 60: 992-997.

35 Variations in the prevalence of respiratory symptoms, self-reported asthma attacks, and use of asthma medication in the European Community Respiratory Health Survey (ECRHS). Eur Respir J 1996; 9: 687-695.

36 Beasley R, Pearce N, Crane J. International trends in asthma mortality. Ciba Found Symp 1997; 206: 140-150.

37 Sunyer J, Anto JM, Tobias A, Burney P. Generational increase of self-reported first attack of asthma in fifteen industrialized countries. European Community Respiratory Health Study (ECRHS). Eur Respir J 1999; 14: 885-891.

38 Beeber SJ. Parental smoking and childhood asthma. J Pediatr Health Care 1996; 10: 58-62.

39 Cook DG, Strachan DP. Health effects of passive smoking. 10: Summary of effects of parental smoking on the respiratory health of children and implications for research. Thorax 1999; 54: 357-366.

40 Ulrik CS, Lange P. Cigarette smoking and asthma. Monaldi Arch Chest Dis 2001; 56: 349-353.

41 Jindal SK, Gupta D. The relationship between tobacco smoke and bronchial asthma. Indian J Med Res 2004; 120: 443-453.

42 Thomson NC, Chaudhuri R, Livingston E. Asthma and cigarette smoking. Eur Respir J 2004; 24: 822-833.

43 Tyc VL, Throckmorton-Belzer L. Smoking rates and the state of smoking interventions for children and adolescents with chronic illness. Pediatrics 2006; 118: e471-e487.

44 Tager IB. The effects of second-hand and direct exposure to tobacco smoke on asthma and lung function in adolescence. Paediatr Respir Rev 2008; 9: 29-37.

45 Wang L, Pinkerton KE. Detrimental effects of tobacco smoke exposure during development on postnatal lung function and asthma. Birth Defects Res C Embryo Today 2008; 84: 54-60.

46 Lemiere C, Boulet LP. Cigarette smoking and asthma: a dangerous mix. Can Respir J 2005; 12: 79-80.

47 Thomson NC, Spears M. The influence of smoking on the treatment response in patients with asthma. Curr Opin Allergy Clin Immunol 2005; 5: 57-63.

48 Livingston E, Thomson NC, Chalmers GW. Impact of smoking on asthma therapy: a critical review of clinical evidence. Drugs 2005; 65: 1521-1536.

49 Xian H, Scherrer JF, Madden PA, et al. The heritability of failed smoking cessation and nicotine withdrawal in twins who smoked and attempted to quit. Nicotine Tob Res 2003; 5: 245-254.

50 Pergadia ML, Heath AC, Martin NG, Madden PA. Genetic analyses of DSM-IV nicotine withdrawal in adult twins. Psychol Med 2006; 36: 963-972. 
51 Rossing MA. Genetic influences on smoking: candidate genes. Environ Health Perspect 1998; 106: 231-238.

52 Arinami T, Ishiguro H, Onaivi ES. Polymorphisms in genes involved in neurotransmission in relation to smoking. Eur J Pharmacol 2000; 410: 215-226.

53 Al Koudsi N, Tyndale RF. Genetic influences on smoking: a brief review. Ther Drug Monit 2005; 27: 704-709.

54 MacLeod SL, Chowdhury P. The genetics of nicotine dependence: relationship to pancreatic cancer. World J Gastroenterol 2006; 12: 7433-7439.

55 Pianezza ML, Sellers EM, Tyndale RF. Nicotine metabolism defect reduces smoking. Nature 1998; 393: 750.

56 Nakajima M, Yamamoto T, Nunoya K, et al. Role of human cytochrome P4502A6 in C-oxidation of nicotine. Drug Metab Dispos 1996; 24: 1212-1217.

57 Messina ES, Tyndale RF, Sellers EM. A major role for CYP2A6 in nicotine C-oxidation by human liver microsomes. J Pharmacol Exp Ther 1997; 282: 1608-1614.

58 Rao Y, Hoffmann E, Zia M, et al. Duplications and defects in the CYP2A6 gene: identification, genotyping, and in vivo effects on smoking. Mol Pharmacol 2000; 58: 747-755.

59 Tyndale RF, Sellers EM. Variable CYP2A6-mediated nicotine metabolism alters smoking behavior and risk. Drug Metab Dispos 2001; 29: 548-552.

60 Ando M, Hamajima N, Ariyoshi N, Kamataki T, Matsuo K, Ohno Y. Association of CYP2A6 gene deletion with cigarette smoking status in Japanese adults. J Epidemiol 2003; 13: 176-181.

61 Fujieda M, Yamazaki H, Saito T, et al. Evaluation of CYP2A6 genetic polymorphisms as determinants of smoking behavior and tobacco-related lung cancer risk in male Japanese smokers. Carcinogenesis 2004; 25: 2451-2458.

62 Schoedel KA, Hoffmann EB, Rao Y, Sellers EM, Tyndale RF. Ethnic variation in CYP2A6 and association of genetically slow nicotine metabolism and smoking in adult Caucasians. Pharmacogenetics 2004; 14: 615-626.

63 London SJ, Idle JR, Daly AK, Coetzee GA. Genetic variation of CYP2A6, smoking, and risk of cancer. Lancet 1999; 353: 898-899.

64 Loriot MA, Rebuissou S, Oscarson M, et al. Genetic polymorphisms of cytochrome P450 2A6 in a casecontrol study on lung cancer in a French population. Pharmacogenetics 2001; 11: 39-44.

65 Carter B, Long T, Cinciripini P. A meta-analytic review of the CYP2A6 genotype and smoking behavior. Nicotine Tob Res 2004; 6: 221-227.

66 Caporaso NE, Lerman C, Audrain J, et al. Nicotine metabolism and CYP2D6 phenotype in smokers. Cancer Epidemiol Biomarkers Prev 2001; 10: 261-263.

67 Saarikoski ST, Sata F, Husgafvel-Pursiainen K, et al. CYP2D6 ultrarapid metabolizer genotype as a potential modifier of smoking behaviour. Pharmacogenetics 2000; 10: $5-10$.

68 Cholerton S, Boustead C, Taber H, Arpanahi A, Idle JR. CYP2D6 genotypes in cigarette smokers and non-tobacco users. Pharmacogenetics 1996; 6: 261-263.

69 Boustead C, Taber H, Idle JR, Cholerton S. CYP2D6 genotype and smoking behaviour in cigarette smokers. Pharmacogenetics 1997; 7: 411-414.
70 De Luca V, Wang H, Squassina A, Wong GW, Yeomans J, Kennedy JL. Linkage of M5 muscarinic and $\alpha_{7}$-nicotinic receptor genes on $15 q 13$ to schizophrenia. Neuropsychobiology 2004; 50: 124-127.

71 Lou XY, Ma JZ, Payne TJ, Beuten J, Crew KM, Li MD. Gene-based analysis suggests association of the nicotinic acetylcholine receptor $\beta_{1}$ subunit (CHRNB1) and M1 muscarinic acetylcholine receptor (CHRM1) with vulnerability for nicotine dependence. Hum Genet 2006; 120: 381-389.

72 Saccone SF, Hinrichs AL, Saccone NL, et al. Cholinergic nicotinic receptor genes implicated in a nicotine dependence association study targeting 348 candidate genes with 3713 SNPs. Hum Mol Genet 2007; 16: 36-49.

73 Silverman MA, Neale MC, Sullivan PF, et al. Haplotypes of four novel single nucleotide polymorphisms in the nicotinic acetylcholine receptor $\beta_{2}$-subunit (CHRNB2) gene show no association with smoking initiation or nicotine dependence. Am J Med Genet 2000; 96: 646-653.

74 Feng $Y$, Niu T, Xing H, et al. A common haplotype of the nicotine acetylcholine receptor $\alpha_{4}$ subunit gene is associated with vulnerability to nicotine addiction in men. Am J Hum Genet 2004; 75: 112-121.

$75 \mathrm{Li} \mathrm{MD}$, Beuten J, Ma JZ, et al. Ethnic- and gender-specific association of the nicotinic acetylcholine receptor $\alpha_{4}$ subunit gene (CHRNA4) with nicotine dependence. Hum Mol Genet 2005; 14: 1211-1219.

76 Staley JK, Krishnan-Sarin S, Cosgrove KP, et al. Human tobacco smokers in early abstinence have higher levels of $\beta_{2}{ }^{*}$ nicotinic acetylcholine receptors than nonsmokers. J Neurosci 2006; 26: 8707-8714.

77 Ehringer MA, Clegg HV, Collins AC, et al. Association of the neuronal nicotinic receptor $\beta_{2}$ subunit gene (CHRNB2) with subjective responses to alcohol and nicotine. Am J Med Genet B Neuropsychiatr Genet 2007; 144B: 596-604.

78 Voineskos S, De Luca V, Mensah A, Vincent JB, Potapova N, Kennedy JL. Association of $\alpha_{4} \beta_{2}$ nicotinic receptor and heavy smoking in schizophrenia. J Psychiatry Neurosci 2007; 32: 412-416.

79 Di Chiara G, Imperato A. Drugs abused by humans preferentially increase synaptic dopamine concentrations in the mesolimbic system of freely moving rats. Proc Natl Acad Sci USA 1988; 85: 5274-5278.

80 Pontieri FE, Tanda G, Orzi F, Di Chiara G. Effects of nicotine on the nucleus accumbens and similarity to those of addictive drugs. Nature 1996; 382: 255-257.

81 Zoli M, Moretti M, Zanardi A, McIntosh JM, Clementi F, Gotti C. Identification of the nicotinic receptor subtypes expressed on dopaminergic terminals in the rat striatum. J Neurosci 2002; 22: 8785-8789.

82 Balfour DJ. The neurobiology of tobacco dependence: a preclinical perspective on the role of the dopamine projections to the nucleus accumbens [corrected]. Nicotine Tob Res 2004; 6: 899-912.

83 Noble EP, St Jeor ST, Ritchie T, et al. D2 dopamine receptor gene and cigarette smoking: a reward gene? Med Hypotheses 1994; 42: 257-260.

84 Comings DE, Ferry L, Bradshaw-Robinson S, Burchette R, Chiu C, Muhleman D. The dopamine D2 receptor (DRD2) 
gene: a genetic risk factor in smoking. Pharmacogenetics 1996; 6: 73-79.

85 Comings DE, Gade R, Wu S, et al. Studies of the potential role of the dopamine D1 receptor gene in addictive behaviors. Mol Psychiatry 1997; 2: 44-56.

86 Shields PG, Lerman C, Audrain J, et al. Dopamine D4 receptors and the risk of cigarette smoking in AfricanAmericans and Caucasians. Cancer Epidemiol Biomarkers Prev 1998; 7: 453-458.

87 Spitz MR, Shi H, Yang F, et al. Case-control study of the D2 dopamine receptor gene and smoking status in lung cancer patients. J Natl Cancer Inst 1998; 90: 358-363.

$88 \mathrm{Wu}$ X, Hudmon KS, Detry MA, Chamberlain RM, Spitz MR. D2 dopamine receptor gene polymorphisms among African-Americans and Mexican-Americans: a lung cancer case-control study. Cancer Epidemiol Biomarkers Prev 2000; 9: 1021-1026.

89 Sullivan PF, Neale MC, Silverman MA, et al. An association study of DRD5 with smoking initiation and progression to nicotine dependence. Am J Med Genet 2001; 105: 259-265.

90 Yoshida K, Hamajima N, Kozaki K, et al. Association between the dopamine D2 receptor A2/A2 genotype and smoking behavior in the Japanese. Cancer Epidemiol Biomarkers Prev 2001; 10: 403-405.

91 Munafo M, Clark T, Johnstone E, Murphy M, Walton R. The genetic basis for smoking behavior: a systematic review and meta-analysis. Nicotine Tob Res 2004; 6: 583-597.

92 Laucht M, Becker K, El-Faddagh M, Hohm E, Schmidt MH. Association of the DRD4 exon III polymorphism with smoking in fifteen-year-olds: a mediating role for novelty seeking? I Am Acad Child Adolesc Psychiatry 2005; 44: 477-484.

93 Bierut LJ, Rice JP, Edenberg HJ, et al. Family-based study of the association of the dopamine D2 receptor gene (DRD2) with habitual smoking. Am J Med Genet 2000; 90: 299-302.

94 Singleton $\mathrm{AB}$, Thomson JH, Morris CM, Court JA, Lloyd S, Cholerton S. Lack of association between the dopamine D2 receptor gene allele DRD2*A1 and cigarette smoking in a United Kingdom population. Pharmacogenetics 1998; 8: 125-128.

95 Johnstone EC, Yudkin P, Griffiths SE, Fuller A, Murphy M, Walton R. The dopamine D2 receptor C32806T polymorphism (DRD2 Taq1A RFLP) exhibits no association with smoking behaviour in a healthy UK population. Addict Biol 2004; 9: 221-226.

96 Lerman C, Caporaso NE, Audrain J, et al. Evidence suggesting the role of specific genetic factors in cigarette smoking. Health Psychol 1999; 18: 14-20.

97 Sabol SZ, Nelson ML, Fisher C, et al. A genetic association for cigarette smoking behavior. Health Psychol 1999; 18: 7-13.

98 Erblich J, Lerman C, Self DW, Diaz GA, Bovbjerg DH. Stress-induced cigarette craving: effects of the DRD2 TaqI RFLP and SLC6A3 VNTR polymorphisms. Pharmacogenomics J 2004; 4: 102-109.

99 Jorm AF, Henderson AS, Jacomb PA, et al. Association of smoking and personality with a polymorphism of the dopamine transporter gene: results from a community survey. Am J Med Genet 2000; 96: 331-334.
100 Vandenbergh DJ, Bennett CJ, Grant MD, et al. Smoking status and the human dopamine transporter variable number of tandem repeats (VNTR) polymorphism: failure to replicate and finding that never-smokers may be different. Nicotine Tob Res 2002; 4: 333-340.

101 McKinney EF, Walton RT, Yudkin P, et al. Association between polymorphisms in dopamine metabolic enzymes and tobacco consumption in smokers. Pharmacogenetics 2000; 10: 483-491.

102 Ito $\mathrm{H}$, Hamajima N, Matsuo K, et al. Monoamine oxidase polymorphisms and smoking behaviour in Japanese. Pharmacogenetics 2003; 13: 73-79.

103 Costa-Mallen P, Costa LG, Checkoway H. Genotype combinations for monoamine oxidase-B intron 13 polymorphism and dopamine D2 receptor TaqIB polymorphism are associated with ever-smoking status among men. Neurosci Lett 2005; 385: 158-162.

104 Ma JZ, Beuten J, Payne TJ, Dupont RT, Elston RC, Li MD. Haplotype analysis indicates an association between the DOPA decarboxylase (DDC) gene and nicotine dependence. Hum Mol Genet 2005; 14: 1691-1698.

105 Freire MT, Marques FZ, Hutz MH, Bau CH. Polymorphisms in the DBH and DRD2 gene regions and smoking behavior. Eur Arch Psychiatry Clin Neurosci 2006; 256: 93-97.

106 Yu Y, Panhuysen C, Kranzler HR, et al. Intronic variants in the dopa decarboxylase (DDC) gene are associated with smoking behavior in European-Americans and African-Americans. Hum Mol Genet 2006; 15: 2192-2199.

107 Zhang H, Ye Y, Wang X, Gelernter J, Ma JZ, Li MD. DOPA decarboxylase gene is associated with nicotine dependence. Pharmacogenomics 2006; 7: 1159-1166.

108 Lerman C, Shields PG, Main D, et al. Lack of association of tyrosine hydroxylase genetic polymorphism with cigarette smoking. Pharmacogenetics 1997; 7: 521-524.

109 Anney RJ, Olsson CA, Lotfi-Miri M, Patton GC, Williamson R. Nicotine dependence in a prospective population-based study of adolescents: the protective role of a functional tyrosine hydroxylase polymorphism. Pharmacogenetics 2004; 14: 73-81.

110 Olsson C, Anney R, Forrest S, et al. Association between dependent smoking and a polymorphism in the tyrosine hydroxylase gene in a prospective population-based study of adolescent health. Behav Genet 2004; 34: 85-91.

111 Colilla S, Lerman C, Shields PG, et al. Association of catechol-O-methyltransferase with smoking cessation in two independent studies of women. Pharmacogenet Genomics 2005; 15: 393-398.

112 Redden DT, Shields PG, Epstein L, et al. Catechol-Omethyltransferase functional polymorphism and nicotine dependence: an evaluation of nonreplicated results. Cancer Epidemiol Biomarkers Prev 2005; 14: 1384-1389.

113 Beuten J, Payne TJ, Ma JZ, Li MD. Significant association of catechol-O-methyltransferase (COMT) haplotypes with nicotine dependence in male and female smokers of two ethnic populations. Neuropsychopharmacology 2006; 31: 675-684.

114 Guo S, Chen da F, Zhou DF, et al. Association of functional catechol O-methyltransferase (COMT) Val108Met polymorphism with smoking severity and 
age of smoking initiation in Chinese male smokers. Psychopharmacology (Berl) 2007; 190: 449-456.

115 Ribeiro EB, Bettiker RL, Bogdanov M, Wurtman RJ. Effects of systemic nicotine on serotonin release in rat brain. Brain Res 1993; 621: 311-318.

116 Mihailescu S, Palomero-Rivero M, Meade-Huerta P, Maza-Flores A, Drucker-Colin R. Effects of nicotine and mecamylamine on rat dorsal raphe neurons. Eur J Pharmacol 1998; 360: 31-36.

$117 \mathrm{Hu}$ S, Brody CL, Fisher C, et al. Interaction between the serotonin transporter gene and neuroticism in cigarette smoking behavior. Mol Psychiatry 2000; 5: 181-188.

118 Lerman C, Caporaso NE, Audrain J, Main D, Boyd NR, Shields PG. Interacting effects of the serotonin transporter gene and neuroticism in smoking practices and nicotine dependence. Mol Psychiatry 2000; 5: 189-192.

119 Lerman C, Caporaso NE, Bush A, et al. Tryptophan hydroxylase gene variant and smoking behavior. Am J Med Genet 2001; 105: 518-520.

120 Sullivan PF, Jiang Y, Neale MC, Kendler KS, Straub RE. Association of the tryptophan hydroxylase gene with smoking initiation but not progression to nicotine dependence. Am J Med Genet 2001; 105: 479-484.

121 Mizuno S, Ito H, Hamajima N, Tamakoshi A, Hirose K, Tajima K. Association between smoking habits and tryptophan hydroxylase gene C218A polymorphism among the Japanese population. J Epidemiol 2004; 14: 94-99.

122 Lerman C, Shields PG, Audrain J, et al. The role of the serotonin transporter gene in cigarette smoking. Cancer Epidemiol Biomarkers Prev 1998; 7: 253-255.

123 Ishikawa $\mathrm{H}$, Ohtsuki $\mathrm{T}$, Ishiguro $\mathrm{H}$, et al. Association between serotonin transporter gene polymorphism and smoking among Japanese males. Cancer Epidemiol Biomarkers Prev 1999; 8: 831-833.

124 Johnstone EC, Yudkin PL, Hey K, et al. Genetic variation in dopaminergic pathways and short-term effectiveness of the nicotine patch. Pharmacogenetics 2004; 14: 83-90.

125 Lerman C, Wileyto EP, Patterson F, et al. The functional $\mu-$ opioid receptor (OPRM1) Asn40Asp variant predicts short-term response to nicotine replacement therapy in a clinical trial. Pharmacogenomics J 2004; 4: 184-192.

126 Yudkin P, Munafo M, Hey K, et al. Effectiveness of nicotine patches in relation to genotype in women versus men: randomised controlled trial. BMJ 2004; 328: 989-990.

127 Dahl JP, Jepson C, Levenson R, et al. Interaction between variation in the $\mathrm{D} 2$ dopamine receptor (DRD2) and the neuronal calcium sensor-1 (FREQ) genes in predicting response to nicotine replacement therapy for tobacco dependence. Pharmacogenomics J 2006; 6: 194-199.

128 Lerman C, Tyndale R, Patterson F, et al. Nicotine metabolite ratio predicts efficacy of transdermal nicotine for smoking cessation. Clin Pharmacol Ther 2006; 79: 600-608.

129 Lerman C, Jepson C, Wileyto EP, et al. Role of functional genetic variation in the dopamine D2 receptor (DRD2) in response to bupropion and nicotine replacement therapy for tobacco dependence: results of two randomized clinical trials. Neuropsychopharmacology 2006; 31: 231-242.

130 Malaiyandi V, Lerman C, Benowitz NL, Jepson C, Patterson F, Tyndale RF. Impact of CYP2A6 genotype on pretreatment smoking behaviour and nicotine levels from and usage of nicotine replacement therapy. Mol Psychiatry 2006; 11: 400-409.

131 Munafo MR, Johnstone EC, Wileyto EP, Shields PG, Elliot KM, Lerman C. Lack of association of 5-HTTLPR genotype with smoking cessation in a nicotine replacement therapy randomized trial. Cancer Epidemiol Biomarkers Prev 2006; 15: 398-400.

132 David SP, Munafo MR, Murphy MF, Walton RT, Johnstone EC. The serotonin transporter 5-HTTLPR polymorphism and treatment response to nicotine patch: follow-up of a randomized controlled trial. Nicotine Tob Res 2007; 9: 225-231.

133 Hutchison KE, Allen DL, Filbey FM, et al. CHRNA4 and tobacco dependence: from gene regulation to treatment outcome. Arch Gen Psychiatry 2007; 64: 1078-1086.

134 Johnstone EC, Elliot KM, David SP, Murphy MF, Walton RT, Munafo MR. Association of COMT Val108/ 158Met genotype with smoking cessation in a nicotine replacement therapy randomized trial. Cancer Epidemiol Biomarkers Prev 2007; 16: 1065-1069.

135 Lee AM, Jepson C, Shields PG, Benowitz N, Lerman C, Tyndale RF. CYP2B6 genotype does not alter nicotine metabolism, plasma levels, or abstinence with nicotine replacement therapy. Cancer Epidemiol Biomarkers Prev 2007; 16: 1312-1314.

136 Munafo MR, Elliot KM, Murphy MF, Walton RT, Johnstone EC. Association of the $\mu$-opioid receptor gene with smoking cessation. Pharmacogenomics J 2007; 7: 353-361.

137 O'Gara C, Stapleton J, Sutherland G, et al. Dopamine transporter polymorphisms are associated with shortterm response to smoking cessation treatment Pharmacogenet Genomics 2007; 17: 61-67.

138 Ray R, Jepson C, Wileyto EP, et al. Genetic variation in $\mu$ opioid-receptor-interacting proteins and smoking cessation in a nicotine replacement therapy trial. Nicotine Tob Res 2007; 9: 1237-1241.

139 David SP, Munafo MR, Murphy MF, Proctor M, Walton RT, Johnstone EC. Genetic variation in the dopamine D4 receptor (DRD4) gene and smoking cessation: follow-up of a randomised clinical trial of transdermal nicotine patch. Pharmacogenomics J 2008; 8: 122-128.

140 Munafo MR, Johnstone EC, Guo B, Murphy MF, Aveyard P. Association of COMT Val108/158Met genotype with smoking cessation. Pharmacogenet Genomics 2008; 18: 121-128.

141 Lerman C, Shields PG, Wileyto EP, et al. Pharmacogenetic investigation of smoking cessation treatment. Pharmacogenetics 2002; 12: 627-634.

142 David SP, Niaura R, Papandonatos GD, et al. Does the DRD2-Taq1 A polymorphism influence treatment response to bupropion hydrochloride for reduction of the nicotine withdrawal syndrome? Nicotine Tob Res 2003; 5: 935-942.

143 Lerman C, Shields PG, Wileyto EP, et al. Effects of dopamine transporter and receptor polymorphisms on smoking cessation in a bupropion clinical trial. Health Psychol 2003; 22: 541-548.

144 Swan GE, Valdes AM, Ring HZ, et al. Dopamine receptor DRD2 genotype and smoking cessation outcome following treatment with bupropion SR. Pharmacogenomics J 2005; 5: 21-29. 
145 Berrettini WH, Wileyto EP, Epstein L, et al. Catechol-Omethyltransferase (COMT) gene variants predict response to bupropion therapy for tobacco dependence. Biol Psychiatry 2007; 61: 111-118.

146 David SP, Brown RA, Papandonatos GD, et al. Pharmacogenetic clinical trial of sustained-release bupropion for smoking cessation. Nicotine Tob Res 2007; 9: 821-833.

147 David SP, Strong DR, Munafo MR, et al. Bupropion efficacy for smoking cessation is influenced by the
DRD2 Taq1A polymorphism: analysis of pooled data from two clinical trials. Nicotine Tob Res 2007; 9: 1251-1257.

148 Lee AM, Jepson C, Hoffmann E, et al. CYP2B6 genotype alters abstinence rates in a bupropion smoking cessation trial. Biol Psychiatry 2007; 62: 635-641.

149 Swan GE, Jack LM, Valdes AM, et al. Joint effect of dopaminergic genes on likelihood of smoking following treatment with bupropion SR. Health Psychol 2007; 26: 361-368. 